\title{
Shared Value Potential of Transporting Cargo via Hyperloop
}

\author{
Max Werner*, Klaus Eissing and Sebastian Langton \\ Helmut Schmidt University, Hamburg, Germany
}

This research estimates the shared value created by constructing a hypothetical Hyperloop to transport cargo along 300 km in Northern Germany. Following Porter and Kramer $(2011,2012)$, we identified and evaluated eight factors that create shared value: travel speed, operating costs, safety, noise pollution, air pollution, climate effect/ carbon footprint, separation effect/property efficiency, and maintenance. Using official data compiled by several German institutes and organizations, we conducted comparative analysis to quantify and compare the above-mentioned factors for Hyperloop and over-the-road cargo transport in Germany. Then, we monetized the individual and collective benefits of the shared value created by Hyperloop replacing a significant share of cargo transported by truck. Our findings indicate that the hypothetical Hyperloop project in Northern Germany would create $€ 660-€ 900$ million of shared value annually. Our research method establishes a framework for assessing future transportation proj-

OPEN ACCESS

Edited by:

Panagiotis Ch. Anastasopoulos, University at Buffalo, USA

Reviewed by:

David John Jaroszweski, University of Birmingham, UK Samuel Labi,

Purdue University, USA

*Correspondence: Max Werner werner.max@me.com

Specialty section:

This article was submitted to Transportation and Transit Systems,

a section of the journal

Frontiers in Built Environment

Received: 30 March 2016

Accepted: 13 July 2016

Published: 02 August 2016

Citation:

Werner M, Eissing K and Langton S (2016) Shared Value Potential of Transporting Cargo via Hyperloop.

Front. Built Environ. 2:17. doi: 10.3389/fbuil.2016.00017 ects, such as Hyperloop, and our findings can be generalized to industrialized nations beyond Germany.

Keywords: transportation, technology, innovation, logistic, shared value, cargo transportation

\section{INTRODUCTION}

When Hyperloop was announced in 2013, the Internet was ablaze over this new, magical form of transportation that promised 1,200 kph speeds (Yarrow, 2013). Google search requests for "Hyperloop," at their peak in 2013, outnumbered searches for "Kuehne \& Nagel" or even "Dachser" by more than double. ${ }^{1}$ The concept of a fifth mode of transportation that was faster than commercial air travel, more energy efficient than train travel, and as accessible as a personal automobile touched a nerve (Musk, 2013).

The performance of Hyperloop technology was not the sole source of enthusiasm. When Hyperloop was announced, a similar concept - evacuated tube transportation (ETT) - celebrated its 14th anniversary without significant notice even though its maximum speeds of 4,000 mph far surpass those of Hyperloop, with comparable efficiency (Oster et al., 2011). The enthusiasm surrounding Hyperloop likely had to do with its originator, Elon Musk. The co-founder of PayPal and Solar City and founder and CEO of SpaceX and Tesla Motors has a well-publicized reputation for making the impossible possible. In fact, the correlation between search requests for "Elon Musk" and those for "Hyperloop" is a strong 0.8 .

Hyperloop needs mass attention and support. It is a multi-billion-dollar infrastructure undertaking and the first megaproject funded via crowdsourcing (Hyperloop Transportation Technologies, 2014). It presents the confluence of customary risks from researching and developing futuristic

${ }^{1}$ Regarding to Google Trends. "Kuehne \& Nagel," "Dachser," and "Hyperloop." 
technology, the well-known risks of huge projects, and unconventional funding (Flyvbjerg et al., 2003). Moreover, the large number of stakeholders affected includes property owners, environmentalists, and political decision-makers, who bet reputations and votes on endorsing such megaprojects.

This exploratory case study examines the potential shared value created by constructing a Hyperloop cargo transport network across $300 \mathrm{~km}$ of Northern Germany (Hyperloop NG). We initially extract four key performance indicators from the Hyperloop Alpha Paper (the Alpha Paper). Released by Tesla Motors and SpaceX in 2013, the Alpha Paper is the groundwork discussion of Hyperloop's concept, technical specifications, and economic feasibility. We identify eight fundamental variables that tie key performance indicators to shared value creation. We calculate and statistically compare the eight fundamental variables individually and collectively. Then, we monetize the individual and collective benefits of the shared value created if Hyperloop NG replaces a significant share of cargo currently transported by truck.

The shared value approach represents the "What's in it for me?" of Hyperloop project for society (Porter and Kramer, 2012). This may be in particular relevant as the Hyperloop project is a megaproject on the first and a high tech project on the other hand. Therefore, it is much likely to be very sensitive to stakeholder satisfaction. Shared value as value that is created for society, in addition to value created for the actual customers, is a key indicator to estimate the realization probability of the Hyperloop in general.

Since the Alpha Paper was released, several studies have considered Hyperloop's engineering aspects. Few address its economic potential beyond intra-project concerns. Only one paper addresses shared value, and it confines itself to the free energy created by solar panels that power Hyperloop (Martin, 2014). This study is the first exploratory empirical assessment of Hyperloop's shared value potential for transporting cargo. As such, its case study for Northern Germany is a framework for shared value assessments of future projects elsewhere.

\section{THE HYPERLOOP SYSTEM}

\section{General Information}

Hyperloop is a tube-based transportation mechanism conceived by scientists at Tesla Motors and SpaceX. Its working principle is that of an evacuated tube housing a capsule that accelerates to speeds surpassing conventional modes of transportation. Its principle appears in earlier transportation concepts, including ETT and Swissmetro (Jufer et al., 1993).

The primary difference between Hyperloop and similar concepts is the functioning of air inside the tube. Whereas the other concepts employ a vacuum to erase air drag, Hyperloop compresses the air inside the tube to a ratio of 20:1. Energy costs to contain the operating environment drop significantly. ${ }^{2}$

The Hyperloop capsule is accelerated by an advanced linear system with a moving motor element mounted on the underside of the capsule and a stationary motor element mounted to the tube (Figure 1). Because of low air resistance, Hyperloop requires those propulsion elements only to accelerate or decelerate in short tube sections. The capsule contains independent brakes and emergency wheels.

Although technological aspects of Hyperloop occupied scientists at Tesla and SpaceX, other problems, especially issues related to land use, appeared at the project's onset. The Hyperloop Alpha Paper suggested building the Hyperloop tube on the hard shoulder of highways atop pylons supporting two tube lanes per pylon. This configuration would avoid use of land held by nongovernmental owners and limit the number of parties negotiating for its use.

The Hyperloop concept was unveiled in a passenger and a passenger-plus-cargo-car version. This study concerns the second version. As described in the Alpha Paper, Hyperloop is intended to relieve existing rail and road infrastructure with a more advanced and efficient technology. Our study quantifies and monetizes that efficiency.

\section{Key Performance Indicators}

The Alpha Paper is the primary source of information about Hyperloop and the source on which ongoing approaches are based. We extracted from it four key performance indicators on which to base estimates of shared value.

\section{Speed}

The Alpha Paper postulates average travel speeds of $300 \mathrm{mph} / 480 \mathrm{kmh}\left(\nu_{u}\right)$ through urban areas and difficult course sections and $760 \mathrm{mph} / 1,220 \mathrm{kmh}\left(\nu_{t}\right)$ through regular course sections.

${ }^{2}$ Detailed numbers for energy efficiency are in Section "Operating Costs."

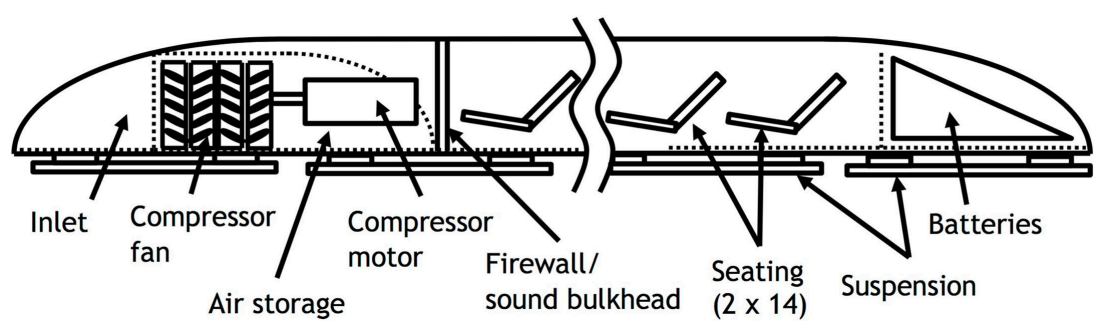

FIGURE 1 | Hyperloop capsule as proposed in the Hyperloop Alpha Paper (Musk, 2013). 
Capsules attained speeds of $200 \mathrm{mph} / 320 \mathrm{kmh}$ (Citron, 2015) in proof-of-concept tests by Hyperloop Transportation Technologies (HTT). This study relies on speeds indicated in the Alpha Paper.

$$
\begin{aligned}
& v_{u}=480 \mathrm{kmh}, \\
& v_{t}=1,220 \mathrm{kmh} .
\end{aligned}
$$

\section{Frequency}

The Alpha Paper indicates that at peak system performance a capsule departs each lane every $30 \mathrm{~s}\left(h_{p}\right)$. On average, one capsule per lane departs every $2 \min \left(h_{A}\right)$. The third but unspecified departure interval is less than every $2 \mathrm{~min}$. Generally, capsules depart on command. We adjust the two specified departure frequencies for demand assumed in the case study.

$$
\begin{aligned}
& h_{A}=0.5 \frac{\text { launch }}{\min }, \\
& h_{P}=2 \frac{\text { launch }}{\min } .
\end{aligned}
$$

\section{Payload}

Although the Alpha Paper does not delineate payloads, it does describe the components and weights of passenger and cargo capsules. Because this study investigates only cargo transport, we adjusted those values (Table 1). For example, we eliminated Interior and Seats, Passengers and Luggage, and lightened Capsule Structure and Doors by $400 \mathrm{~kg}$ to befit cargo transport. We assumed an average cargo payload of $12,000 \mathrm{~kg}\left(l_{c}\right)$.

$$
l_{C}=12,000 \mathrm{~kg}
$$

\section{Energy Consumption}

Hyperloop was designed to be self-powered by solar arrays atop its tube. The Alpha Paper estimates that the larger cargo version of the Hyperloop capsule consumes an average $66,000 \mathrm{hp} / 49 \mathrm{MW}$ to operate bi-directionally. However, that estimate is based on solar

\begin{tabular}{|c|c|c|c|}
\hline $\begin{array}{l}\text { Capsule component } \\
\text { (alpha) }\end{array}$ & $\begin{array}{l}\text { Weight } \\
\text { (kg) }\end{array}$ & $\begin{array}{l}\text { Payload component } \\
\text { adjusted }\end{array}$ & $\begin{array}{c}\text { Weight } \\
\text { (kg) }\end{array}$ \\
\hline $\begin{array}{l}\text { Capsule structure and } \\
\text { doors }\end{array}$ & 3,500 & Capsule structure and doors & 3,100 \\
\hline Interior and seats & 2,700 & Propulsion system & 800 \\
\hline Propulsion system & 800 & Suspension and air bearings & 1,300 \\
\hline $\begin{array}{l}\text { Suspension and air } \\
\text { bearings }\end{array}$ & 1,300 & Batteries, motor, and coolant & 5,500 \\
\hline $\begin{array}{l}\text { Batteries, motor, and } \\
\text { coolant }\end{array}$ & 5,500 & Air compressor & 2,500 \\
\hline Air compressor & 2,500 & Emergency braking & 800 \\
\hline Emergency braking & 800 & Payload & 12,000 \\
\hline Passengers and luggage & 1,400 & & \\
\hline Car and cargo & 7,500 & & \\
\hline Total & 26,000 & Total & 26,000 \\
\hline
\end{tabular}
conditions in California. For operations in Northern Germany, we assumed worst-case energy consumption of $49 \mathrm{MW}$ for $h_{A}\left(P_{A}\right)$. The Alpha Paper indicates that launching one capsule consumes

TABLE 1 | Capsule and payload components.
$0.5 \%$ of all required energy. A departure frequency of $h_{A}$ demands 14.7 MWh. More frequent departures $\left(h_{p}\right)$ raise energy required by $29.4 \mathrm{MWh}\left(P_{p}\right)$.

$$
\begin{gathered}
P_{A}=49 \mathrm{MWh}, \\
P_{P}=78.4 \mathrm{MWh} .
\end{gathered}
$$

\section{RESEARCH METHODOLOGY}

\section{Evaluating Shared Value}

Shared value is seldom calculated for projects that are not operating when they are studied. Given the singularity of the Hyperloop project, especially its crowdsource funding, assessing shared value is essential to assessing its benefits. The evaluation involved four steps.

First, we identified relevant shared value factors that represent potential benefits to society by transporting cargo via Hyperloop in the hypothesized market.

Second, we identified eight fundamental variables and quantified their absolute changes as indicators of heightened or diminished potential shared value.

Third, we monetized the shared value of each fundamental variable using published European data for external costs to transport cargo. If paired comparisons were not available, we monetized variables independently as if their shared value potential had been realized.

Fourth, we calculated total shared value as the sum of each monetized shared value. The following example illustrates this evaluation:

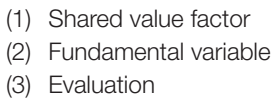

Travel time

Reduced travel time

Monetized value of reduced travel time

= Shared value for the shared value "travel time" factor

\section{Difficulties, Limitations, and Case Study Assumptions}

Our paper is purely explorative in nature and has been written while the actual Hyperloop technology passed the conceptual stage (early 2016). Naturally, multiple difficulties are the consequence of our approach. While the absolute number of difficulties is hard to define, we focus on the explanation of the following three difficulties, which we regard as the primary difficulties. Follow-up studies may use this as starting point for additional research.

\section{The Difficulty to Compare}

The Hyperloop is a theoretical concept that has passed the conceptual stage for the first major steps toward an alpha prototype. The number of academic studies or official reliable data, therefore, is limited. For our study on the Shared Value Potential of Transporting Cargo via Hyperloop, it is especially difficult to identify an already existing cargo transportation system that is suitable to be compared with the Hyperloop. As the Hyperloop is planned to be a point-to-point transportation system, it seems intuitive to compare it with equal 
point-to-point services as air or train transportation. We have deliberately decided against the more intuitive transportation systems as basis of comparison.

The foundation of this decision lays in the perspective. While air and train transportation may seem promising from the perspective of the defining criteria, they certainly are not regarding the Hyperloop's Shared Value Potential for Transporting Cargo. From the perspective of the Hyperloop's potential, it seems counter-intuitive to compare a much more promising concept with secondary or tertiary cargo transportation systems. The benchmark for cargo transportation in Germany is road freight transportation with above $70 \%$ of market share (Statista, 2015). To evaluate the Hyperloop's Shared Value potential from the perspective of the actual benchmark potential, we therefore compare the Hyperloop as multimodal transport service substituting point-to-point segments of door-to-door road freight transportation.

\section{The Development Progress}

One of the most significant limitations of our paper is the fact that the Hyperloop technology is still under development, while this paper has been written. Changes in content and underlying assumptions, therefore, are the natural consequence. As time passes, the quality of this paper might drop significantly as more information become official or are generally available. To overcome this issue and provide early explorative data regarding the Hyperloop's Shared Value Potential for Transporting Cargo, we decided to use the Hyperloop Alpha Paper as primary source regarding the Hyperloop technical specifications. It seems likely that this source is the least common multiple of all follow-up technical papers and, therefore, most reliable.

Concluding, we would like to add that the aim of this paper is to provide explorative data especially at this early stage to evaluate the Hyperloop's Potential and as a consequence help to justify resource allocations on other research and technical projects.

\section{The Necessity to Assume}

As already indicated, it is necessary to take assumptions to close major information gaps that were not available at the early stage of the Hyperloop development. Naturally, those assumptions are weak points of our paper. The following lines should indicate the assumptions taken for our paper and strengthen the argumentation on the basis of official and academic sources. We assume that published documentation and official statistics describing Hyperloop, its technical performance, and demographics of Hyperloop NG's hypothetical market are reliable, although we acknowledge that actual implementation remains far distant.

\section{Technical Features}

We assume Hyperloop NG is a two-lane, tube-based, pylonmounted, cargo transportation infrastructure that exhibits the key performance indicators in Section "Key Performance Indicators" and is in line with the Hyperloop Alpha Paper. For simplicity, we assume that it has only two stations at the beginning and end of its route that are capable of transshipping all incoming or outgoing cargo. Prior studies indicate its capsule can transport $87 \%$ of statistically identified types of cargo (Werner, 2014).

\section{Target Market}

Following the procedure recommended by HTT's Crowdstorm Documentation, we situated the hypothetical Hyperloop in Northern Germany. We examined several infrastructure networks there and chose that offering superior market potential. Comprehensive market potential for Hyperloop NG is hard to assess. We presuppose there are no intermediate substations (i.e., interim delivery points) along its hypothetical route; therefore, we can calculate values only for cargo transported along entire course sections.

Statistisches Bundesamt (2013a,b) provides selected data for quantities of cargo transported among Germany's 16 federal states and more detailed data for its three city-states. We use its figures for the industrially relevant cities to calculate the adjusted amount of cargo transported as the share of total cargo transported in the respective state. We use published data for the markets served (Statistisches Bundesamt, 2013a,b).

Hyperloop NG is $\sim 300 \mathrm{~km}$ long (Figure 2). It connects three federal states, four major cities, and two of Germany's biggest industrial harbors. In 2013, 19,396,000 t of payload transited among the three states (Bundesinstitut für Bau- Stadt- und Raumforschung, 2012). Hence, market size, urban growth, and an infrastructure-friendly setting endorse Hyperloop NG's potential for transporting cargo (Werner, 2014).

Consistent with Hyperloop's founding purpose, we assume Hyperloop NG will supplant some of the rising quantity of cargo transported over-the-road in Northern Germany (Werner, 2014).

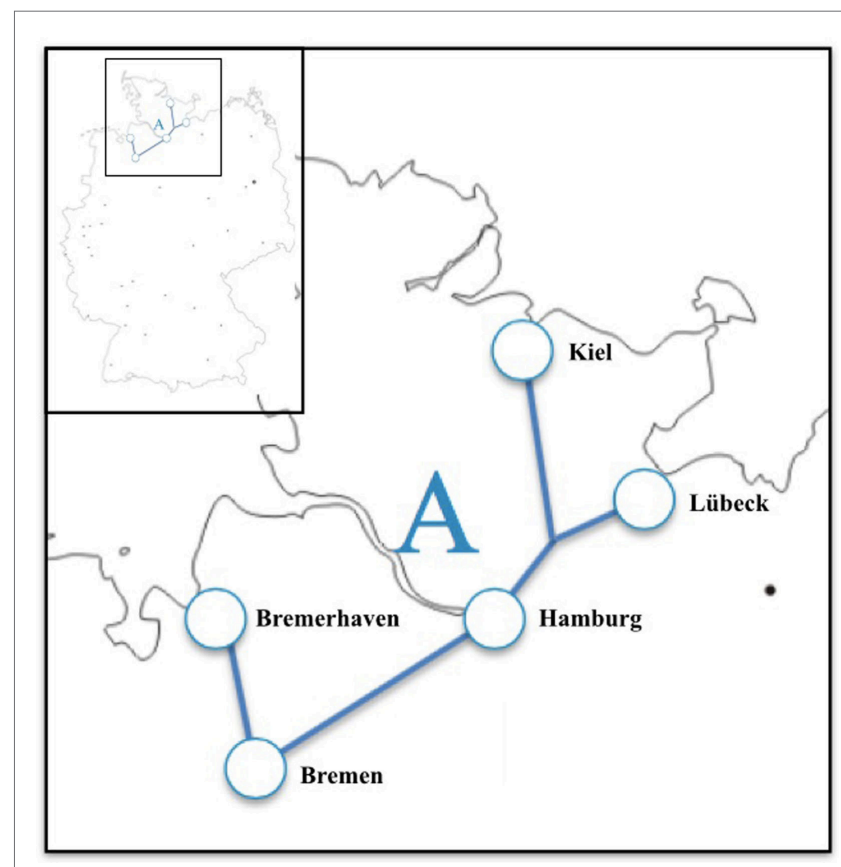

FIGURE 2 | Hypothetical target market - Hyperloop NG Network 


\section{SHARED VALUE}

\section{Identification}

Porter and Kramer (2011) define shared value creation as the integration of social welfare into economic value within a business model. Business models that capture shared value include socially focused start-ups like Indiegogo or Sanergy, the managements of which realize that enhancing social welfare presents large opportunities (Porter and Kramer, 2012). Shared value is the creation of new value. It does not originate from extant value propositions.

Porter and Kramer identify three characteristics of value creation that we used in identifying shared value factors underlying Hyperloop NG's development:

\section{Reconceiving Products and Markets}

Porter and Kramer argue that developing new products or services to meet unmet societal needs creates shared value for society and businesses at the same time. By addressing the needs of disadvantaged communities as well as developing countries, these new markets can trigger fundamental innovation for traditional markets.

\section{Redefining Productivity in the Value Chain}

Redefining productivity in the value chain through the fields of energy use and logistics, resource use, procurement, distribution, employee productivity, and location reduces negative externalities, such as air and noise pollution during the production process. While companies save internal costs, benefits for society ranges from less environmental impact to better social surroundings for employees, suppliers, and distributers. As a first example, Kramer and Porter mention logistical systems, which were redesigned to reduce internal costs and environmental pollution.

\section{Local Cluster Development}

Productivity and innovation of a company are influenced by the local business environment and infrastructure. This cluster also includes educational, political, and economic institutions. Strengthening of the local community leads to a positive impact on a company's financial and economic capacity, performance, and vice versa.

Apart from delivering packages sooner, a Hyperloop that transports cargo seemingly does not benefit households - although we do confirm important indirect benefits. Households may even suffer inconvenience during its construction (e.g., traffic jams). Applying Hyperloop technology to public transportation would engender direct benefits, but that remains for later study.

\section{Analysis}

\section{Travel Speed}

Hyperloop would significantly reduce the time to transport goods between cities.

\section{Cargo Transport Time}

Although it is hard to define average speeds for all categories of cargo trucks and along specific sections of road, Pumberger et al. (2015) estimate average speed for trucks on German highways at $85 \mathrm{kmh}$. We assume trucks average $30-50 \mathrm{kmh}$ on roads leading to highways, as that is the customary speed limit on German secondary roads. Assuming a road-to-highway ratio between 20/80 and 30/70, cargo trucks in Germany average 69-78 kmh.

Table 2 indicates speeds for theoretical Hyperloop Alpha. The Alpha Paper assumes the cargo capsule accelerates at a uniform $0.5 \mathrm{~g}$ toward maximum speed of 1,200 kmh (Musk, 2013). Thus, average speed across all course sections of Hyperloop NG approximates $1,054 \mathrm{kmh}^{3}$

Hyperloop infrastructure would boost average cargo transportation speed $1,350 \%$. Accelerated delivery times redefine productivity throughout the supply chains of industries that ship via the faster infrastructure. Faster cargo transport speed qualifies as level two shared value on Porter-Kramer's index.

\section{Average Travel Speed}

Hyperloop indirectly would raise average travel speeds for highway drivers. Given starting frequency $h_{A}$, payload $l_{c}$, and relative operating percentages of $75-90 \%$ annually (opday annual) while operating 16-24 h daily (ophour $r_{d a y}$ ), Hyperloop could transport $3.2-5.7$ million tons of payload yearly $\left(l_{\text {annual }}\right)$.

$$
l_{\text {annual }}=2 l_{c} \cdot 60 h_{A} \cdot \text { opday }_{\text {annual }} \cdot \text { ophour }_{\text {day }}(5)+(3) \mid(10)
$$

Nearly $38 \%$ of German trucks are empty on return trips (Hütter, 2013), and the average payload per truck is $15 \mathrm{t}$ (Krapf, 2001). Therefore, Hyperloop would supplant 214,000-380,000

${ }^{3}$ We do not calculate shipment loading and processing times, which arguably are identical for transport over the road and via Hyperloop.

\section{TABLE 2 | Average speed.}

\begin{tabular}{|c|c|c|c|c|c|c|c|}
\hline Course section & $\begin{array}{l}\text { Length } \\
\text { (km) }\end{array}$ & $\begin{array}{c}\text { Acceleration } \\
\left(\mathrm{m} / \mathrm{s}^{2}\right)\end{array}$ & $\begin{array}{l}\text { Max speed } \\
(\mathrm{km} / \mathrm{h})\end{array}$ & $\begin{array}{c}\text { Acceleration } \\
\text { time (s) }\end{array}$ & $\begin{array}{l}\text { Acceleration } \\
\text { distance (km) }\end{array}$ & $\begin{array}{c}\text { Travel } \\
\text { time (s) }\end{array}$ & $\begin{array}{c}\text { Average } \\
\text { speed (km h) }\end{array}$ \\
\hline Kiel-Hamburg & 107 & 4.905 & 1220 & 69.09 & 11.71 & 384.83 & 1000.97 \\
\hline Kiel-Bremen & 224 & 4.905 & 1220 & 69.09 & 11.71 & 730.07 & 1104.55 \\
\hline Kiel-Bremerhaven & 285 & 4.905 & 1220 & 69.09 & 11.71 & 910.07 & 1127.38 \\
\hline Lübeck-Hamburg & 76 & 4.905 & 1220 & 69.09 & 11.71 & 293.35 & 932.67 \\
\hline Lübeck-Bremen & 177 & 4.905 & 1220 & 69.09 & 11.71 & 591.39 & 1077.47 \\
\hline Lübeck-Bremerhaven & 246 & 4.905 & 1220 & 69.09 & 11.71 & 794.99 & 1113.97 \\
\hline Hamburg-Bremen & 110 & 4.905 & 1220 & 69.09 & 11.71 & 393.68 & 1005.89 \\
\hline \multirow[t]{2}{*}{ Hamburg-Bremerhaven } & 165 & 4.905 & 1220 & 69.09 & 11.71 & 555.98 & 1068.39 \\
\hline & & & & & & Total average & 1053.91 \\
\hline
\end{tabular}


trucks yearly and reduce highway traffic 1.12-1.99\% (Bundesregierung, 2015).

Although a reduction of $1.12-1.99 \%$ seems unimpressive, it pertains only to truck traffic, which comprises $20 \%$ of crowded, daytime highway traffic (Bundesministerium für Verkehr, 1990). In absolute numbers, the total truck amount of 10,107 per day would be reduced to $1,042(5.8-10.3 \%$ as for the respective scenario). Forschungsgesellschaft für Straßen und Verkehrswesen (2015) categorizes four percentages of truck concentration on highways: below 5, 5-10, 10-20\%, and over 20\%. Each increase reduces road capacity 100-200 cars per hour. Anticipated reductions in the lower categories suggest a higher capacity of 150-300 cars per hour on roads along Hyperloop NG. Holtermann et al. (2015) estimate that traffic volume along Hyperloop NG's route will fluctuate between 64 and $94 \%$. Traffic volume $<75 \%(>75 \%)$ is defined as unencumbered (encumbered) (Forschungsgesellschaft für Straßen und Verkehrswesen, 2015).

Displacing truck traffic rates as level one shared value creation on Porter's index.

\section{Operating Costs}

Hyperloop reduces cargo transport costs, creating non-industrial, and industrial shared value.

\section{Cargo Transportation Cost}

Average costs of transporting cargo by train in Germany are 2.5-5 euro cents per ton per kilometer; average cost of transporting cargo by truck is 10 euro cents per tons per kilometer (Fraunhofer Institut, 2013). Even so, 72\% of German goods are transported by truck, and that share is rising without foreseeable change (Hütter, 2013) primarily because shippers value the flexibility of highway shipments over rigid train schedules.

The Hyperloop competes with truck transport. However, Hyperloop is likely to offer shippers slightly lower costs because of its singular technology. Moreover, Bruns et al. (2010) rank considerations that affect German shippers' choice of transport and find that flexible scheduling ranks a distant fourth behind price, reliability, and speed. Accordingly, Hyperloop appears competitive. ${ }^{4}$

Energy is Hyperloop's main operating expense. Germany's average 2014 price for industrial energy was 8.44 euro cents per $\mathrm{kWh}\left(p_{\text {energy }}\right) .^{5}$ With peak energy consumption $\left(P_{p}\right)$ of $78.4 \mathrm{MWh}$, Hyperloop NG would spend $€ 18-€ 58$ million yearly on energy.

Detailed data for consumption over specific tube distances are unavailable, but the $49 \mathrm{MW}$ indicated in the Alpha Paper likely exceeds Hyperloop NG's actual requirements. This statistical imprecision may serve as a buffer against other computational uncertainties with respect to results that are more in favor with the Hyperloop technology. ${ }^{6}$

Hyperloop incurs costs for coolant water (negligible) monitoring (like all operational systems), and perhaps for transshipping

${ }^{4}$ Hyperloop outperforms every competing transportation concept for speed and reliability. Detailed information appears in Sections "Travel Speed" and "Safety." ${ }^{5}$ Price according to Eurostat.

${ }^{6}$ Energy demand of $49 \mathrm{MW}$ was originally proposed for the distance between Los Angeles and San Francisco (620 km+). cargo. We pessimistically assume that these costs are $80-100 \%$ of total energy cost (factor of 1.8). ${ }^{7}$

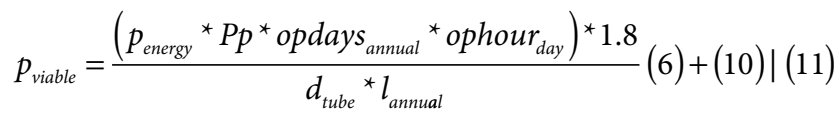

Calculated for the 3.2-5.7 million tons of cargo potentially transported by Hyperloop NG, its viable price $\left(p_{\text {viable }}\right.$ ) would be 1.9-6.8 euro cents per ton per kilometer without the buffering factor. Including the buffer factor the viable price would be in between 3.4 and 9.8 euro cents per ton per kilometer. As Hyperloop NG expands and economies of scale take effect, this cost presumably declines.

The average costs of transporting cargo by train or truck in Germany cannot be compared directly with the viable price of transporting cargo by Hyperloop. Additional non-variable (fixed) costs like e.g., infrastructure investment costs need to be considered to calculate the comparable average costs. In respect of the scope of our paper and the early stage of the Hyperloop development, we have decided to not calculate the final, comparable costs. Nevertheless, the Hyperloop will not define itself through far superior cargo transportation costs, but it seems likely that it will be competitive from our perspective.

\section{Traffic Density}

Hyperloop NG would replace 214,000-380,000 trucks yearly, enlarge roadway capacity by $150-300$ cars per hour, and increase average travel speeds along its route. In doing so, it would reduce transportation costs by reducing fuel consumption. Mohamed (2012) estimates fuel savings of $€ 62$ yearly per vehicle in Germany. The reduction in truck traffic could produce savings reaching $€ 163$ million yearly. Those savings raise Hyperloop NG's shared value for Germany's industrial and household sectors.

Hyperloop enhancement to the industrial supply chain and logistical competitiveness qualify as level two shared value creation on Porters scale. The non-industrial approach is a satisfaction of society's demand for freer traffic flow and lower transportation costs.

\section{Safety}

Hyperloop potentially will reduce the number of accidents by reducing volume of over-the-road cargo, and its technology presents less exposure to operations that produce accidents.

\section{Accident Occurrence}

Transporting cargo via Hyperloop requires minimal human involvement, the primary cause of accidents. Of the 18,452 accidents on German highways in 2013, 11,240 (60\%) involved cargo vehicles (Statistisches Bundesamt, 2014a) and 5,504 (29\%) featured truck drivers as their primary cause (Statistisches Bundesamt, 2014b).

Approximately 1,293,000 trucks each bearing $15 \mathrm{t}$ of payload transported cargo across the route anticipated for Hyperloop NG

\footnotetext{
${ }^{7}$ Hyperloop's transshipment and monitoring costs tie to energy demand. As launch frequency rises, more cargo needs to be transshipped and monitored. 
in 2013. By supplanting 214,000-380,000 trucks, Hyperloop NG potentially reduces the number of yearly accidents by $922-1,660$ (5-9\%). Given death rates in accidents involving trucks, Hyperloop NG could prevent 80-144 traffic deaths yearly.

Also, Hyperloop systems and standards were established for travel between earthquake-prone Los Angeles and San Francisco. Northern Germany presents considerably fewer equivalent hazards.

\section{Reliability}

No extant data endorse Hyperloop's reliability, but the following considerations suggest that it is more reliable than rival systems.

Hyperloop infrastructure is generally immune to external factors like weather, other drivers, or daylight. Each capsule is equipped with emergency power and interconnected emergency brakes. Depressurization or structural failure within the tube activates all brakes equally. Absent large-scale accidents, capsules cannot become stranded within the tube and float on air without propulsion. A capsule can slow only as it approaches acceleration patterns ${ }^{8}$ and stations. Both likely are located near emergency exits. The capsule can negotiate the short distance between exits using its independent emergency wheel system.

By minimizing human participation in transporting cargo, Hyperloop becomes more reliable as well as safer. Enhanced safety also raises the reliability of transporting cargo through freer flow of industrial and non-industrial traffic.

Hyperloop's prospective safety represents level one shared value creation, and its reliability represents level two shared value creation on Porter's index.

\section{Noise Pollution}

Road freight creates noise pollution, a matter of concern in conservation areas or cities. The attendant costs range from mere annoyance to hearing damage from noises above $85 \mathrm{db}$ and greater risk of cardiovascular disease (Essen et al., 2011).

Hyperloop NG transits no conservation areas, and its hypothetical course ends before reaching urban Kiel, Lübeck, and Bremerhaven. Therefore, we consider potential noise pollution only for sections transiting Bremen $(22-38 \mathrm{~km})$, Hamburg (35-55 km), and intervening villages (a pooled area of $18-32 \mathrm{~km}$ ). In total, $75-125 \mathrm{~km}$ are subject to noise pollution along Hyperloop NG.

According to governmental sources, the section near Hamburg encompasses 11,250-18,750 people (Landesbetrieb Straßen Brücken und Gewässer, 2009) and the section near Bremen 2,950-5,100 (Deputation für Umwelt Bau Verkehr Stadtentwicklung und Energie Bremen, 2014). We estimated the number of affected villagers based on the length of course sections and their rural population density of 1,200-2,100 persons. Overall, noise pollution from Hyperloop NG potentially affects 15,400-25,950 people.

${ }^{8}$ Acceleration patterns serve as congestion patterns.
However, its effect likely is negligible. Hyperloop's closed system generates almost no internal noise. The air cushion pressing against the tube's interiors wall can stimulate the tube to swing and create noise. The likelihood this noise will be damaging (>50 db) is comparatively small, and tubes can be adjusted to minimize it (Forschungsgesellschaft für Straßen und Verkehrswesen, 2015). The telling consideration is that Hyperloop NG potentially reduces noise pollution by supplanting $214,000-380,000$ trucks yearly along its course.

Reduced noise pollution qualifies as level one shared value creation on Porter's index.

\section{Air Pollution}

German society understands the value of less-polluting technologies (Osberghaus et al., 2013). As a self-empowering system that could supplant extensive cargo traffic, Hyperloop could transform over-the-road freight transport into a cleaner industry.

We calculated an average carbon footprint for the 214,000380,000 trucks Hyperloop NG could supplant yearly because no precise data allow computations by type of truck in Northern Germany. We used total over-the-road freight transport in 2010 in Germany (Statista, 2015). The calculation was performed through the rule of three per ton per kilometer for methane, nitrous oxide, nitrous gases, non-methane gasses, volatile organic components, sulfur dioxide, and dust.

(1) Emissions per pollutant in Germany created by over-theroad freight transport

(2) Total emissions by pollutant in Germany (Thomas, 2012)

(3) Total over-the-road freight transport figures in Germany during the respective years of data (2010)

(4) The rule of three for emissions in German over-the-road transport per pollutant scaled per ton per kilometer

(5) Substituted road-freight performance was calculated in the Operating Costs section.

(6) Multiplying 4 and $5=$ Total substituted emissions per pollutant from Hyperloop NG

(7) Relative substitution per pollutant in Germany 2.

Computations indicate that Hyperloop NG curtails emissions of $654-1,160 \mathrm{~kg}$ of methane, 4,170-7,405 kg of nitrous oxide, $596-1,057 \mathrm{~kg}$ of nitrous gases, $26,715-47,438 \mathrm{~kg}$ of non-methane volatile organic components, 1,902-3,377 kg of sulfur dioxide, and $15,527-27,571 \mathrm{~kg}$ of dust yearly. Hyperloop NG potentially abates $0.0146-0.2317 \%$ of emissions of these respective pollutants in Germany. That achievement qualifies as level one shared value creation on Porter's index.

Those calculations ignore that Hyperloop is powered by solar energy, which produces the fewest pollutants of any power source in industrial Germany's energy mix.

\section{Climate Effect/Carbon Footprint}

German over-the-road freight transport produced 49,610,000 $\left(C O 2_{G E R \_R F T}\right)$ tons of carbon dioxide in 2010 . In relation to Germany's road-freight traffic volume of 440,600,000,000 per ton per kilometer (GER_RFT), the industrial sector produces 
$112 \mathrm{~g}$ of $\mathrm{CO}_{2}$ per ton per kilometer. The 3.2-5.7 million tons of cargo transported by truck over Hyperloop NG's $300 \mathrm{~km}$ $\left(l_{\text {annual }}\right)$ would produce $107,520-191,520$ tons of $\mathrm{CO}_{2}$ yearly $\left(\mathrm{CO} 2_{\text {subst. }}\right){ }^{9}$

$$
C O 2_{\text {subst. }}=\frac{C O 2_{G E R_{-} R F T}}{G E R_{-} R F T} l_{\text {annual }}(10) \mid(12)
$$

Transporting cargo only via solar-powered Hyperloop NG is not possible in North Germany as for the geographical location. Solar energy produced on top of the Hyperloop NG would not be able to empower the system itself (SMA, 2015). The linear expansion of the solar panel structure leads to long-distance supply systems. In combination with the comparatively low energy yield in North Germany, there is no effective use of solar energy possible.

The average energy mix in Germany industry creates 542 g/ $\mathrm{kWh}$ of $\mathrm{CO}_{2}\left(\mathrm{CO}_{\text {mix }}\right)$ (Icha, 2014). Transporting 3.2 to 5.7 million tons over $300 \mathrm{~km}$ via Hyperloop NG would create 26.56-42.49 t of $\mathrm{CO}_{2}$ per hour.

$$
\begin{aligned}
\Delta \mathrm{CO} 2_{\text {annual }}= & \mathrm{CO} 2_{\text {mix }}{ }^{\star} P^{\star} \text { opdays }_{\text {annual }} \text { * ophour } \\
& -\mathrm{CO} 2_{\text {subst }}(6)+(12) \mid(13)
\end{aligned}
$$

The total reduction in annual $\mathrm{CO}_{2}\left(\Delta C O 2_{\text {annual }}\right)$ would be $8,919-143,981 \mathrm{t}$. This achievement qualifies as level one creation of shared value on Porter's index.

\section{Separation Effect and Property Efficiency}

From 2030 to 2050, German road-freight traffic will rise yearly from $4.11 \%$ (Shell, 2010) to $4.33 \%$ (Ickert et al., 2007) over best-case $6.19 \%$ to worst-case $8.78 \%$ yearly (Prokop and Stoller, 2012). ${ }^{10}$ Given delays from traffic jams, construction, and rush hour bottlenecks, enhancing that road capacity is a major issue. There are three likely scenarios.

${ }^{9}$ Calculated for the total German road-freight performance $/ 21,300 \mathrm{~km}$ of supraregional roads.

${ }^{10}$ Best case in the sense of the limited traffic volume capacity.

\section{Substitution}

A decline in regular road travel offsets a rise in over-the-road freight transport. This is a short-term and temporary potential solution because society must pay additional taxes for major road damages that accrue a welfare loss (Kopper et al., 2013), as is already happening in Germany (Sieg et al., 2014).

\section{Efficiency}

With technical development, especially through autonomous driving, road capacity in urban areas and on highways could be increased significantly (Campbell et al., 2010). Cost is the problematic issue under this scenario. Advancing vehicle technology requires investment capital, costs of which will raise the average price and open opportunities for less modern vehicles. Such is already happening with modern $\mathrm{CO}_{2}$-efficient trucks. The only significant effect is that it increases the cabotage share.

\section{Construction}

Adding road capacity occasions tremendous costs, increases the separation effect ${ }^{11}$ by widening highways, and consumes land. To compare the capacity of Hyperloop with existing highway infrastructure, we calculated relative capacity. Relative to their width, highways have a capacity of 4,230 cars per $1.5 \mathrm{~m}$ and require $450,000 \mathrm{~m}^{2}$ of land surface (Forschungsgesellschaft für Staßen- und Verkehrswesen, 2008).

Figure 3 shows that Hyperloops add no separation to existing highways. They require $1.5 \times 2.0 \mathrm{~m}$ of land for each pylon, and pylons are spaced every $30 \mathrm{~m}$, allowing people, animals, or pedestrians to cross. Hyperloop NG would require 30,000 $\mathrm{m}^{2}$ (Werner, 2014) and enhance road capacity by 3,600-7,200 cars per day by reducing truck traffic.

Hyperloop NG creates shared value by avoiding the separation effect, increasing traffic capacity, and freeing road traffic. These qualify as level one shared value creation on Porter's index.

\footnotetext{
${ }^{11}$ Separation in this sense means additional property that is blocked through transportation infrastructure.
}

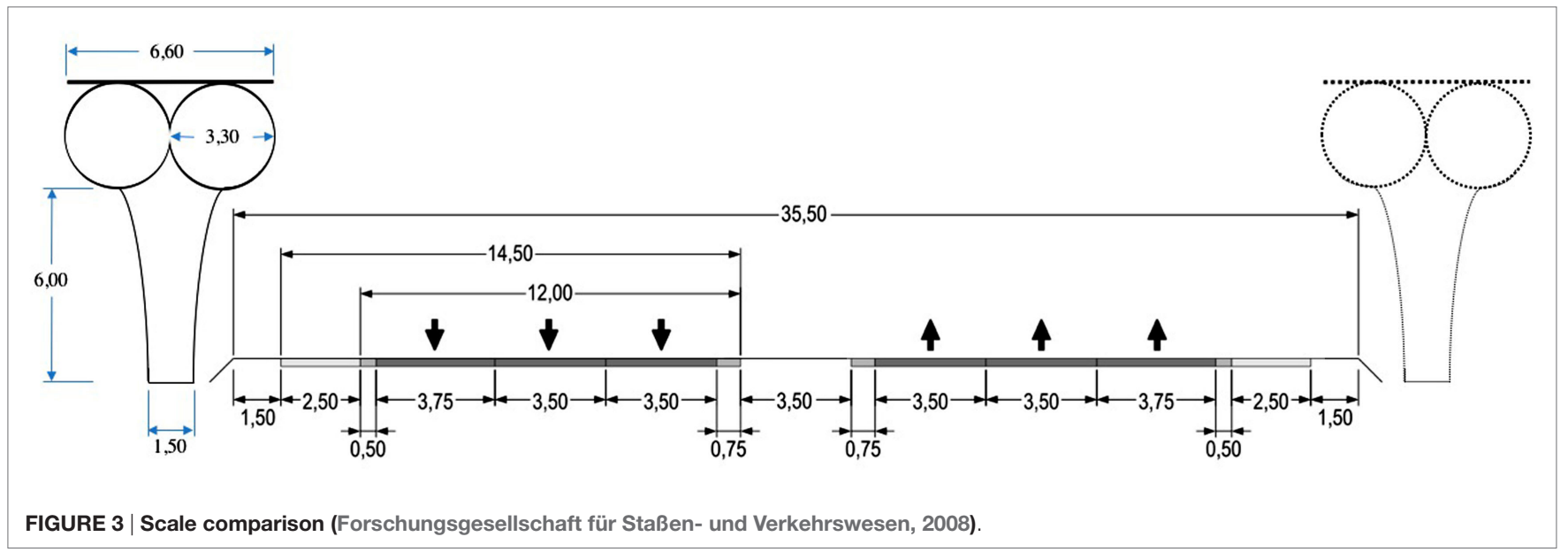




\section{Running Maintenance Costs}

Hyperloop was conceived to close the economic inefficiencies of existing tube-based high-speed transportation concepts. Especially, regarding its air cushion suspension, Hyperloop is expected to have negligible non-routine maintenance costs.

By supplanting truck traffic, Hyperloop reduces road damage. German highways suffer $€ 7.5$ billion in damage yearly ( $p_{\text {dmg }}$ ) (ADAC e.V, 2015), and Cebon (1993) estimates that one-third could be prevented by reducing truck traffic. Relative to the 453.6-billion-per ton per kilometer road-freight traffic volume in Germany in 2013 (GER_RFT_13), 1.65 euro cents of damage is caused per ton per kilometer.

$$
p_{\text {substdmg }}=l_{\text {annual }} * d_{\text {tube }} * \frac{p_{\text {dmg }}}{G E R \_R F T_{-} 13}(10) \mid(14)
$$

Hyperloop NG would supplant 3.2-5.7 million tons of cargo $\left(l_{\text {annual }}\right)$ transported by truck $\left(d_{\text {tube }}\right)$. That represents a potential savings of $€ 15.89-€ 28.22$ million yearly in road damage ( $p_{\text {substdmg }}$ ).

Curtailing road damage also would reduce repair-related traffic jams and raise average speed. Given the limited availability of data, however, we disregard the value created.

Reducing costs of road damage qualifies as level one creation of shared value on Porter's index.

\section{Monetary Evaluation}

Table 3 displays the monetized shared value for each of the eight factors discussed. Fundamental variables that cannot be monetized because of data uncertainties are indicated.

\section{Cargo Transportation Time}

We calculated the value of this factor using average speeds for Hyperloop and regular trucks along Hyperloop NG. We compared the time needed for both to transport cargo and calculated the percentage decrease in time as a change in the variable. Given insufficient data for the value of time in the logistics industry, we took a bridge-approach. We calculated the created value of time on the road by multiplying the number of hours Germans spend in traffic jams by estimated cost of time lost (Hoppe, 2004). As an estimate result, the Hyperloop NG would generate up to $€ 401$ million of shared value per year through the reduction of cargo transportation travel time.

\section{Average Travel Speed}

Measuring highway capacity in cars per hour is difficult, and the sole scholarly attempt to do so involves transforming a four-lane highway to a six-lane highway. Nonetheless, that study sets the monetary value of time saved through higher average speeds along Hyperloop NG at $€ 0.55-€ 1.1$ million per year (Brilon, 2004).

\section{Cargo Transportation Price}

At this early stage of development and with the limitations of the Hyperloop fixed cost components, even with price data available, it is hard to monetize actual benefits from the Hyperloop industry overall. Therefore, we exclude this factor in computing total shared value (Fraunhofer Institut, 2013).

\section{Density of Traffic}

We analyzed fuel savings occasioned by fewer traffic jams along Hyperloop NG's $300 \mathrm{~km}$. We compared costs of additional fuel consumed per car and the addition of 150-300 cars per hour to the highway along its course. Potential fuel savings are $€ 81,468,000-€ 162,930,000$ (Mohamed, 2012).

TABLE 3 | Total shared value calculation. ${ }^{a}$

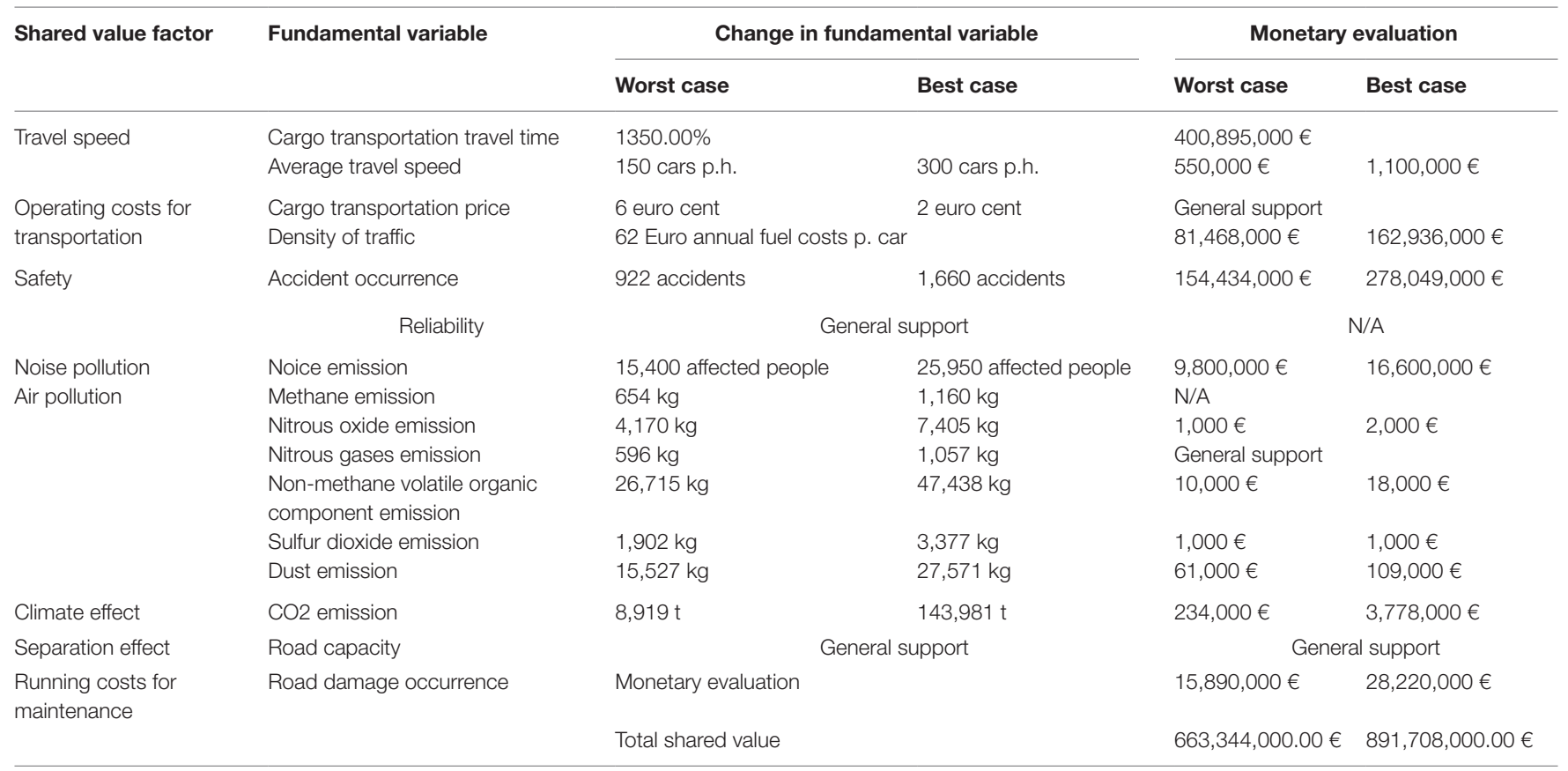

aRounded to thousands. EUR/USD $=1.05$. 


\section{Accident Occurrence}

By reducing the number of trucks on the road, Hyperloop NG would prevent 922-1,660 accidents yearly. Among these, $80-144$ would have been fatal and cost $€ 587,392-€ 1,057,305$ plus $€ 23,432-€ 42,178$ in physical damage. Estimating 296-533 fewer serious injuries and 543-978 uninjured people, we calculated total savings in between $€ 154$ and $€ 278$ millions using comprehensive data for external costs (Bundesanstalt für Straßenverkehrswesen, 2014).

\section{Reliability}

Calculating detailed value created through Hyperloop's safe operation requires additional data. Nevertheless, operational reliability raises operational safety, and we calculated that value in our discussion of speed. Therefore, the shared value factor of Hyperloop safety supports the shared value of cargo transportation speed (Musk, 2013).

\section{Noise Pollution}

The external costs to people affected by noise pollution are defined in the literature. With 214,000-380,000 fewer trucks yearly and average noise pollution of $65 \mathrm{db}$ affecting $15,400-25,950$ people, Hyperloop NG could reduce costs from noise pollution by $€ 9.8-€ 16.6$ million yearly (Essen et al., 2011).

\section{Air Pollution}

The external costs of air pollution are partially defined in the literature. Costs for methane and nitrous gas emissions are unavailable. We calculated yearly $€ 73.000-€ 130.000$ of shared value created using the decreased rates figured in the analysis (Verhoef, 1994).

\section{Climate Effect}

Carbon dioxide emissions can be traded and, therefore, have a visible price. As Hyperloop is an impending project, we calculated value creation using the average price per ton of $\mathrm{CO}_{2}$ forecast for 2020 and 2050 (Luckow et al., 2015). The Hyperloop NG would create in between $€ 0,23$ and $€ 3,78$ million per year.

\section{Separation Effect}

It is hard to evaluate changes in the variable for this factor, so we did not monetize it. However, it likely is positive because Hyperloop NG's separation effect is minimal (Bickel and Friedrich, 1995). This statistical imprecision may serve as a buffer against other computational uncertainties.

\section{Road Damages}

We calculated the value of precluded road damages using their total cost of $€ 7.5$ billion in Germany. For total transportation performance, we calculated 1.65 euro cents per ton per kilometer. Multiplied by the substituted road freight performance by Hyperloop, the monetary evaluation of road damages was realized (Statistisches Bundesamt, 2015). Concluding the Hyperloop NG would generate $€ 15,9-€ 28,2$ million of shared value per year.

\section{CONCLUSION}

Transporting cargo via Hyperloop benefits society through faster travel speeds, reduced transportation costs, greater safety, less noise and air pollution, fewer climate effects, smaller carbon footprints, minimal separation effects, enhanced property efficiency, and lower maintenance costs. This study has calculated the shared value created by constructing a hypothetical Hyperloop in Northern Germany, rated its benefits using Porter's shared value index, and monetized that shared value for eight factors individually and in total. In doing so, it is the first study to suggest how benefits of Hyperloop technology can be assessed concretely. Although our findings pertain to Germany, our method provides a way to assess Hyperloop's contributions in industrialized nations generally.

Our results show that Hyperloop creates significant shared value. In the least case, Hyperloop NG's higher speeds create value worth $€ 400$ million yearly. By reducing the number of accidents, it creates $€ 150$ million yearly in shared value. In total, the eight shared value factors examined here represent $€ 660-€ 900$ million of shared value likely to be created yearly by constructing Hyperloop NG. Given Hyperloop NG's calculated performance and the rule of three governing pollutants, onethird of an investment of $€ 2.7$ billion would be recoupled in shared value creation.

This study is exploratory and presented as an impetus for future research, which needs to confirm the robustness of our estimates and their variability. In particular, future research can compute the benefits of reducing methane and nitrous gas emissions, for which German data were unavailable, and better assess Hyperloop's energy requirements per tube distance as its technology advances. Equally important, future research can adjust our estimates of operating costs as Hyperloop technology - particularly use of magnetic suspension systems - advances.

Hyperloop addresses issues significant to modern transportation. Although estimates and implications presented here will change with time and national circumstances, shared value potential should be incorporated into assessments of Hyperloop's development. As evidenced by the shared value documented here, Hyperloop technology promises to alter how the industrialized world transports cargo.

\section{AUTHOR CONTRIBUTIONS}

MW: full research paper. KE: engineering and project management expertise. SL: practical and logistic expertise.

\section{ACKNOWLEDGMENTS}

I would like to thank Dirk Ahlborn for constructive talks and indepth insights. My thanks also go to Prof. Dr. Niemeyer and Prof. Dr. Beckmann for their motivation and academic assistance. It is only with the help of the mentioned people that this manuscript is what it is. 


\section{REFERENCES}

ADAC e.V. (2015). Immer Weniger Straßen Werden Repariert. Available at: https:// www.adac.de/infotestrat/adac-im-einsatz/motorwelt/strassenschaeden.aspx

Bickel, P., and Friedrich, R. (1995). Was kostet uns die Mobilität? Berlin: Springer.

Brilon, W. (2004). Zufallscharakter der Kapazität von Autobahnen und praktische Konsequenzen In: Deutscher Straßen- und Verkehrskongress, Straßenverkehrstechnik (Vol. 49/Issue 4). (Berlin: Forschungsgesellschaft für Straßen- und Verkehrswesen (FGSV)), 1-35.

Bruns, A. S., Zelewski, S., and Klumpp, M. (2010). Trends in der Güterverkehrslogistik. Essen: Institut für Produktion und Industrielles Informationsmanagement, $1-27$.

Bundesanstalt für Straßenverkehrswesen. (2014). Volkswirtschaftliche Kosten von Straßenverkehrsunfällen in Deutschland. Bergisch Gladbach: Bundesanstalt für Straßenwesen.

Bundesinstitut für Bau- Stadt- und Raumforschung. (2012). Regionales Monitoring (Stuttgart: Initiativkreis Europäische Metropolenregionen in Deutschland (IKM)), 7-11.

Bundesministerium für Verkehr. (1990). Richtlinie für den Lärmschutz an Straßen. Köln: BfV.

Bundesregierung. (2015). Verkehrssituation auf Deutschlands Straßen. Available at: https://www.bundesregierung.de/Content/DE/Magazine/MagazinInfrastruktur NeueLaender/014/s1-verkehrssituation-auf-deutschlands-strassen.html

Campbell, M., Egerstedt, M., How, J. P., and Murray, R. M. (2010). Autonomous driving in urban environments: approaches, lessons and challenges. Philos. Trans. A Math. Phys. Eng. Sci. 368, 4649-4672. doi:10.1098/rsta.2010.0110

Cebon, D. (1993). Interaction between heavy vehicles and roads. SAE Int. 62, 253-264. doi:10.4271/930001

Citron, R. (2015). Hyperloop Glides Toward Reality in California. Available at: https://www.navigantresearch.com/blog/hyperloop-glides-toward-realityin-california

Deputation für Umwelt Bau Verkehr Stadtentwicklung und Energie Bremen. (2014). Aktionsplan zur Lärmminderung nach der Umgebungslärmrichtlinie. Bremen: Bremer Stadtverwaltung.

Essen, H. V., Schroten, A., Otten, M., Sutter, D., Schreyer, C., Zandonella, R., et al. (2011). External Costs of Transport in Europe. Delft: CE Delft, Infras, Fraunhofer ISI Delft.

Flyvbjerg, B., Bruzelius, N., and Rothengatter, W. (2003). Megaprojects and Risk. Cambridge: Cambridge University Press.

Forschungsgesellschaft für Staßen- und Verkehrswesen. (2008). Richtlinien für die Anlage von Autobahnen RAA. Köln: FGSV-Verlag.

Forschungsgesellschaft für Straßen und Verkehrswesen. (2015). Richtlinien für Wirtschaftlichkeitsuntersuchungen an Straßen. Köln: FGSV Verlag.

Fraunhofer Institut. (2013). Infoblatt 5/5: Bahngüterverkehr. Available at: http:// www.isi-projekt.de/wissprojekt-wAssets/docs/ntm-downloads/infoblaetter/ fhs_Infoblatt_5.pdf

Holtermann, L., Jahn, M., Otto, A. H., and Wedemeier, J. (2015). Metropolregion Hamburg 2020: Verkehrsinfrastruktur und ihre Auslastung. Available at: http://www.hwwi.org/fileadmin/hwwi/Publikationen/Partnerpublikationen/ HSH/150415_Verkehr_Studie_web.pdf

Hoppe, H. (2004). Externe Kosten des Verkehrs. Hessen: BUND.

Hütter, A. (2013). Verkehr auf einen Blick. Wiesbaden: Statistisches Bundesamt.

Hyperloop Transportation Technologies. (2014). Crowdstorm Documentation (El Segundo: Hyperloop Transportation Technologies), 1-76.

Icha, P. (2014). Entwicklung der spezifischen Kohlendioxid-Emissionen des deutschen Strommix in den Jahren 1990 bis 2013. Dessau-Rosslau: Für Mensch \& Umwelt. Umweltbundesamt.

Ickert, L., Matthes, U., Rommerskirchen, S., Weyand, E., Schlesinger, M., and Limbers, J. (2007). Abschätzung der langfristigen Entwicklung des Güterverkehrs in Deutschland bis 2050. Basel: Bundesministerium für Verkehr, Bau und Stadtentwicklung.

Jufer, M., Perret, F.-L., Descoeudres, F., and Trottet, Y. (1993). Swissmetro, an efficient intercity subway system. Struct. Eng. Int. 3, 184-189. doi:10.2749/101686693780607921

Kopper, C., Hartwig, K.-H., Rothengatter, W., Gawel, E., and Eisenkopf, A. (2013). Die Verkehrsinfrastruktur in Deutschland: marode und unterfinanziert. Wirtschaftsdienst 93, 659-677. doi:10.1007/s10273-013-1582-5

Krapf, H. (2001). Verkehrslenkung durch Abgaben. Münster: LIT.
Landesbetrieb Straßen Brücken und Gewässer. (2009). Lärmschutz an Hamburger Autobahnen. Hamburg: Hamburger Stadtverwaltung.

Luckow, P., Stanton, E. A., Fields, S., Biewald, B., Jackson, S., Fisher, J., et al. (2015). 2015 Carbon Dioxide Price Report. Massachusetts: Synapse Energy Economics Inc.

Martin, S. J. (2014). Creating Shared Economic Value for Arizonans by Proliferating Solar through the Hyperloop Project. Available at: http://repository.asu.edu/ items $/ 23296$

Mohamed, S. (2012). The Economic Costs of Gridlock. London: Centre for Economics and Business Research Ltd.

Musk, E. (2013). Hyperloop Alpha. Available at: http://www.spacex.com/sites/ spacex/files/hyperloop_alpha.pdf

Osberghaus, D., Schwirplies, C., and Ziegler, A. (2013). Klimawandel in Deutschland: Risikowahrnehmung, Wissensstand und Anpassung in privaten Haushalten. Essen: Rheinisch-Westfälisches Institut für Wirtschaftsforschung e.V.

Oster, D., Kumada, M., and Zhang, Y. (2011). Evacuated tube transport technologies (ET3) tm: a maximum value global transportation network for passengers and cargo. J. Mod. Transp. 19, 42-50. doi:10.1007/BF03325739

Porter, M. E., and Kramer, M. R. (2011). Creating shared value. Harvard Bus Rev $89,62-77$

Porter, M. E., and Kramer, M. R. (2012). "Shared value: die Brücke von Corporate Social Responsibility zu Corporate Strategy," in Corporate Social Responsibility, eds A. Schneider and R. Schmidpeter (Berlin Heidelberg: Springer), 137-153.

Prokop, G., and Stoller, A. (2012). Der Güterverkehr von morgen. Heinrich Böll Stiftung Schriften zur Ökologie 30, 1-118.

Pumberger, A., Fessl, T., and Authried, N. (2015). Lkw-Geschwindigkeitsverhalten auf Autobahnen. Wien: Verkehr und Infrastruktur, 1-127.

Shell. (2010). Shell Lkw-Studie. Hamburg: Shell Deutschland Oil GmbH.

Sieg, G., Wieland, B., Knieps, G., Puls, T., Beckmann, K. J., Bernecker, T., et al. (2014). Pkw-Maut, Sonderabgabe oder Sonderfonds: Sinnvolle Instrumente zur Finanzierung der Verkehrsinfrastruktur? ifo Schnelldienst 67, 3-28.

SMA. (2015). Solarstromrechner - Ergebnis. Available at: http://www.sma.de/ home-systems/solarrechner.html

Statista. (2015). Transportleistung im deutschen Straßengüterverkehr. Hamburg: Statista.

Statistisches Bundesamt. (2013a). Verkehr. Available at: https://www.destatis. de/DE/Publikationen/Thematisch/TransportVerkehr/Querschnitt/ VerkehrAktuellPDF_2080110.pdf

Statistisches Bundesamt. (2013b). Verkehr im Überblick. Wiesbaden: Fachserie Statistisches Bundesamt.

Statistisches Bundesamt. (2014a). Verkehr. Wiesbaden: Fachserie Statistisches Bundesamt.

Statistisches Bundesamt. (2014b). Verkehrsunfälle. Fachserie Verkehr. Wiesbaden: Statistisches Bundesamt.

Statistisches Bundesamt. (2015). Autobahnnetz in Deutschland in 2014. Wiesbaden: Statistisches Bundesamt.

Thomas, J. (2012). Umweltökonomische Analyse des Güterverkehrs 1995 bis 2010. Bergisch Gladbach: Wirtschaft und Statistik, Statistisches Bundesamt, $1-13$.

Verhoef, E. (1994). External effects and social costs of road transport. Transp. Res. Part A Policy Pract. 28, 273-287. doi:10.1016/0965-8564(94)90003-5

Werner, M. (2014). Hypercargo. Ein deutscher Hyperloop nach Transrapid und Co? München: GRIN Verlag.

Yarrow, J. (2013). Elon Musk Has Plans for a New, Magical Form of Transportation Called the Hyperloop. TSLA. Available at: http://www.seattlepi.com/technology/businessinsider/article/Elon-Musk-Has-Plans-For-A-New-MagicalForm-Of-4561606.php

Conflict of Interest Statement: The authors declare that the research was conducted in the absence of any commercial or financial relationships that could be construed as a potential conflict of interest.

Copyright (c) 2016 Werner, Eissing and Langton. This is an open-access article distributed under the terms of the Creative Commons Attribution License (CC BY). The use, distribution or reproduction in other forums is permitted, provided the original author(s) or licensor are credited and that the original publication in this journal is cited, in accordance with accepted academic practice. No use, distribution or reproduction is permitted which does not comply with these terms. 